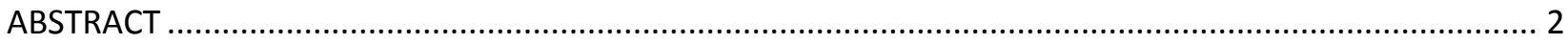

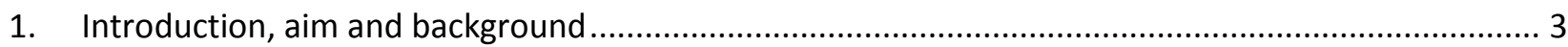

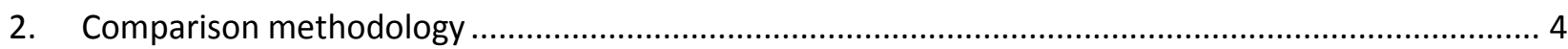

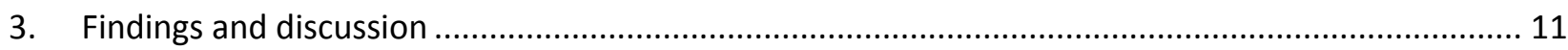

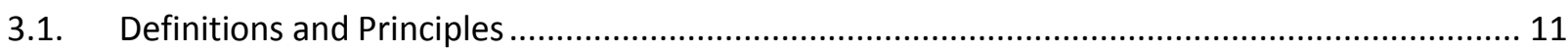

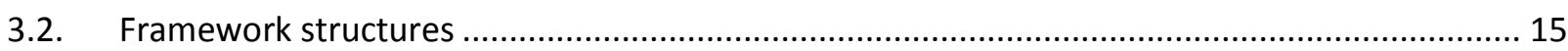

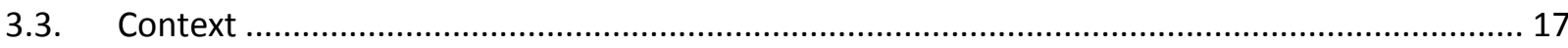

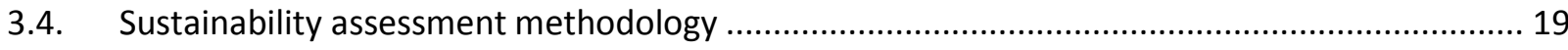

3.5. Provision of Terminology/Vocabulary ....................................................................................... 20

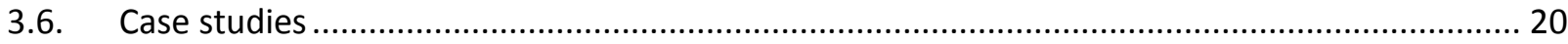

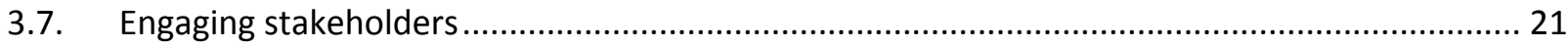

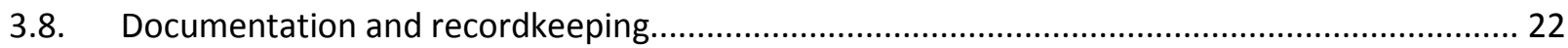

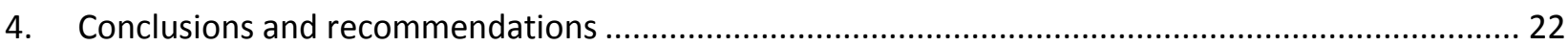

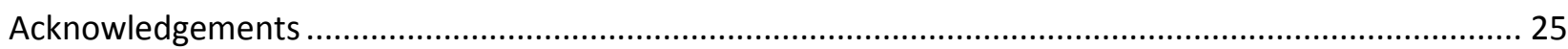

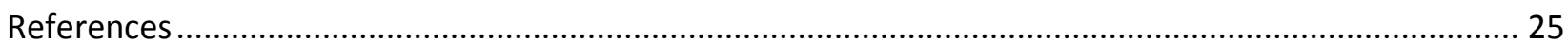




\section{Comparison of international approaches to sustainable remediation}

Erika Rizzo ${ }^{1}$, Paul Bardos ${ }^{2}$, Lisa Pizzol ${ }^{1}$, Andrea Critto ${ }^{1 *}$, Elisa Giubilato ${ }^{1}$, Antonio Marcomini ${ }^{1}$, Claudio Albano $^{3}$, Dominique Darmendrail ${ }^{4}$, Gernot Döberl ${ }^{5}$, Melissa Harclerode ${ }^{6}$, Nicola Harries ${ }^{7}$, Paul Nathanail ${ }^{8}$, Carlos Pachon ${ }^{9}$, Alfonso Rodriguez ${ }^{10}$, Hans Slenders ${ }^{11,12}$, Garry Smith ${ }^{13}$.

${ }^{1}$ University Ca' Foscari of Venice, Dept. of Environmental Sciences Informatics and Statistics, Via delle Industrie 21/8, c/o INCA - VEGAPARK, 30175 Marghera-Venice, Italy.

${ }^{2}$ University of Brighton, Brighton UK; and r3 Environmental Technology Ltd., Reading, UK.

${ }^{3} \mathrm{CH} 2 \mathrm{MHILL}$ Senior Project Manager, via XXV Aprile, 2, S. Donato Milanese (Mi) 20097, Italy; and SuRF ItalyRECONNET chairman.

${ }^{4}$ Common Forum on Contaminated Land in Europe, Paris, France.

${ }^{5}$ Environment Agency Austria, Department for Contaminated Sites, Vienna, Austria.

${ }^{6}$ Montclair State University, New Jersey, USA; and CDM Smith, New Jersey, USA.

${ }^{7} \mathrm{CL}:$ AIRE, London, UK.

${ }^{8}$ University of Nottingham, Nottingham, UK; and Land Quality Management Ltd, Nottingham, UK.

${ }^{9}$ U.S. Environmental Protection Agency, Washington DC, USA.

${ }^{10}$ r3 Environmental Technology Colombia SAS, Bogotá, Colombia.

${ }^{11}$ Network for Industrially Contaminated Land in Europe, NICOLE Secretariat, P.O. Box 28249, 3003 KE Rotterdam, The Netherlands.

${ }^{12}$ ARCADIS Nederland B.V., Arnhem, The Netherlands.

${ }^{13}$ Geosyntec Senior Consultant; and Chairman of SuRF Australia \& New Zealand.

*Corresponding author:

Dr. Andrea Critto, Associate Professor, University Ca' Foscari of Venice, Dept. of Environmental Sciences Informatics and Statistics, Via delle Industrie 21/8, c/o INCA - VEGAPARK, 30175 Marghera-Venice, Italy. Tel. 0039-0412348579; e-mail: critto@unive.it.

\section{ABSTRACT}

Since mid-to-late 2000s growing interest for sustainable remediation has emerged in initiatives from several international and national organisations as well as other initiatives from networks and forums. This reflects a realisation that risk-management activities can about bring environmental, social, and economic impacts (positive or negative) in addition to achieving risk-based remediation goals. These ideas have begun to develop as a new discipline of "sustainable remediation". The various initiatives have now published a number of frameworks, standards, white papers, road maps and operative guidelines. The similarities and differences in the approaches by these outputs and general trends have been identified. The comparison is based on a set of criteria developed in discussion with members of these various 
initiatives, and identifies a range of similarities between their publications. Overall the comparison demonstrates a high level of consensus across definitions and principles, which leads to the conclusion that there is a shared understanding of what sustainable remediation is both across countries and stakeholder groups. Publications do differ in points of detail, in particular about the operational aspects of sustainable remediation assessment. These differences likely result from differences in context and legal framework. As this analysis was carried out its findings were debated with members of the various international initiatives, many of whom have been included as authors. Hence the outcomes described in this paper can be seen as the result of a sort of multi-level debate among international experts (authors) and so can offer a starting point to new sustainable remediation initiatives (for example in other countries) that aim to start developing their own documents.

Keywords: sustainable remediation; sustainable brownfield regeneration; green remediation; sustainability appraisal; sustainable remediation approaches comparison; sustainable remediation trends.

\section{Introduction, aim and background}

A wide range of industrial, waste disposal, infrastructure and other land uses have left a legacy of contamination at numerous sites and operating facilities all over the world (Van Liedekerke et al., 2014; USA EPA, 2004; Brombal et al., 2015; Bolton et al., 2013). In countries with regulatory frameworks and programmes dealing with contaminated sites, the most common approach for managing historically contaminated land has, for a long time, been based on the mitigation of unacceptable risks to human health and the environment including, and in many cases predominantly, ensuring such land is rendered suitable for a new use at the time of changing the land use (Vegter et al., 2001). Until recently, the acts of remediation and regeneration have been considered to comprise de facto a sustainable form of development, based on practices focused on reusing existing infrastructure (utilities, roads, etc.), relieving pressure on greenfield development, and yielding additional environmental benefits in water and air quality as well as reductions in greenhouse gas emissions among others (US EPA, 2015). However, by the 1990s, the wider environmental and other sustainability impacts of remediation had also emerged as an important topic (Bardos et al., 2002).

"Sustainable Development" has been defined as development that meets the needs of the present without compromising the ability of future generations to meet their own needs (Brundtland, 1987). In recent years, several collaborative initiatives worldwide have begun to more formally apply sustainable development principles to the management of contaminated sites and brownfields (Bardos, 2014) building on these earlier considerations. In September 2015 the United Nations has set 17 sustainable development goals (SDG) with an explicit concern over land degradation (United Nations, 2015)

The first of these initiatives, specifically initiated with the aim of developing the concept of sustainable remediation, was the Sustainable Remediation Forum (SURF) established in 2006 in the USA. Subsequently, similar working groups have been established in Australia/New Zealand, Brazil, Canada, Colombia, Italy, Taiwan, The Netherlands and UK. All have the aim of promoting sustainable remediation.

The two principal European land contamination stakeholder networks, the Common Forum on Contaminated Land (hereafter Common Forum) and the Network for Industrially Contaminated Land in Europe (NICOLE), have also been active. SustRem, a series of international conferences specifically dedicated to sustainable remediation began in Copenhagen in 2009 followed by meetings in Vienna, Austria (2012) and Ferrara, Italy (2014) (Döberl et al., 2012; Albano et al., 2014), and is planned to continue in 2016 in Canada (RPIC, 2015). These various activities have ensured a good cross-fertilisation of ideas. In addition, since 2012, representatives of a number of different SuRFs have set up a slightly more formal structure of 
on-line meetings on a quarterly basis (www.claire.co.uk/surfinternational). Also in 2012 a working group on sustainable remediation was set up under the auspices of the International Organization for Standardization (ISO).

A wide range of publications and other outputs (e.g., frameworks, road maps for implementation) have been produced over a relatively short period of time from these sustainable remediation initiatives. The aim of this paper is to present and compare these various frameworks and related documents on sustainable remediation by describing similarities and differences in approach, identifying general trends. To do this, the published frameworks and related documents have been collated, analysed and compared by a small team centred at the University of Venice on a preliminary basis. The preliminary comparison (and its criteria) was then circulated to the various initiatives mentioned, who were then invited to contribute and debate the comparison to provide a more substantive comparison and outcome. Hence members of most of the various sustainable remediation initiatives listed have been directly involved in the preparation of this comparison paper in order to obtain shared results.

In this paper Section 2 outlines the document sources and presents the comparison methodology used in the assessment (see Figure 2), Section 3 presents the results and the discussion, and Section 4 reports conclusions.

\section{Comparison methodology}

The first step was the identification of appropriate sources of information to include in this comparison. Table 1 shows the initiatives, and more specifically the networks and the forums, considered as sources of information. They are divided according to the continent they belong to, and listed in alphabetic order.

Table 1 Initiatives considered as sources* of information.

\begin{tabular}{|c|c|c|c|c|c|}
\hline $\begin{array}{l}\text { Europe } \\
\text { - Common } \\
\text { Forum**; } \\
\text { - NICOLE; } \\
\text { - SuRF-Italy; } \\
\text { - SuRF-NL**; } \\
\text { - SuRF-UK. }\end{array}$ & $\begin{array}{l}\text { North and South } \\
\text { America**** } \\
\text { - ASTM***** } \\
\text { (American for } \\
\text { Society and } \\
\text { Testing } \\
\text { Materials); } \\
\text { - ITRC; } \\
\text { - Sustainable } \\
\text { Remediation } \\
\text { Forum } \\
\text { (SURF******); } \\
\text { - SuRF-Brazil; } \\
\text { - SuRF-Canada; } \\
\text { - SuRF-Colombia }\end{array}$ & $\begin{array}{l}\text { Asia } \\
\text { - SuRF-Taiwan. }\end{array}$ & $\begin{array}{l}\text { Australia and } \\
\text { New Zealand } \\
\text { - SuRF-Australia } \\
\text { and New } \\
\text { Zealand. }\end{array}$ & $\begin{array}{l}\text { Africa } \\
\text { / }\end{array}$ & $\begin{array}{l}\text { International } \\
\text { - International } \\
\text { Committee on } \\
\text { Contaminated Land } \\
\text { ICCL, international } \\
\text { regulators and } \\
\text { policy-makers } \\
\text { network allied to } \\
\text { the COMMON } \\
\text { FORUM. } \\
\text { - International } \\
\text { Organization for } \\
\text { Standardization } \\
\text { (ISO). }\end{array}$ \\
\hline
\end{tabular}

*A complete list of the analysed frameworks and related documents is reported in Annex 1 of Supplementary material.

**Common Forum on Contaminated Land in the European Union.

*** The SuRF-NL framework document differs from the other initiatives reviewed. The scope of SuRF-NL extends to Sustainable Land Management, which can also include Soil Protection measures in addition to remediation.

**** A number of Public Sector organisations in the USA have produced guidance documents, which attempt to merge green and sustainable remediation guidance to some degree (ITRC, 2011a, 2011b; MPCA, 2012; USACE, 2010; U.S. Navy 2012; and WDNR, 2012). This paper focuses on SURF, ITRC and ASTM as the other guidance documents are broadly derivative of these and "green remediation" guidance.

*****ASTM E2876-13 Standard Guide for Integrating Sustainable Objectives into Clean-up.

****** SURF in the US is always referred to just as "SURF" as it was the first one established.

While this paper primarily analyses contaminated land management, a number of the documents reviewed contextualise sustainable remediation in relation to sustainable brownfield regeneration, therefore some explanation of these contexts is necessary. Sustainable remediation and sustainable brownfield 
regeneration can be seen as overlapping domains in the wider context of sustainable land development as shown in Error! Reference source not found..

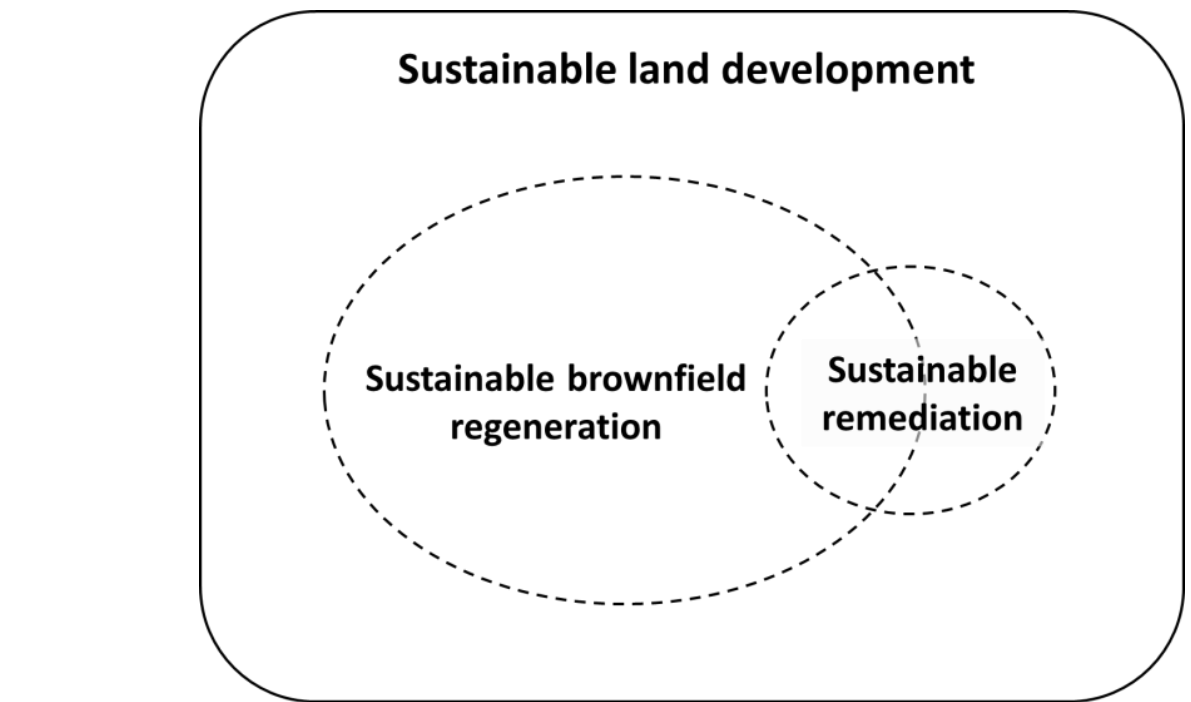

Figure 1 Sustainable land development, sustainable brownfield regeneration and sustainable remediation.

The European RESCUE project (Regeneration of European Sites in Cities and Urban Environments) defined sustainable brownfield regeneration as "the management, the rehabilitation and return to beneficial use of the brownfield land resource base in such a manner as to ensure the attainment and continue satisfaction of human needs for present and future generations in environmentally non-degrading, economically viable, institutionally robust and social acceptable ways" (RESCUE, 2002). This definition was also adopted by the European project HOMBRE (Holistic Management of Brownfield Regeneration) (HOMBRE, 2014) and TIMBRE (Tailored Improvement of Brownfield Regeneration in Europe) (TIMBRE, 2014).

The European CABERNET Project underlined the significance of brownfield regeneration for sustainable land development and the importance of sustainability objectives setting (CABERNET, 2006). CABERNET defined brownfields as sites that "have been affected by the former uses of the site and the surrounding land; are derelict or underused; may have real or perceived contamination problems; are mainly in developed urban areas; require intervention to bring them back to beneficial use". Therefore, while brownfields are not necessarily contaminated, contaminated land management may be an important part of many brownfield redevelopment or restoration projects. The recent European HOMBRE (2014) and TIMBRE (2014) projects have explicitly linked sustainable remediation and brownfields reuse agendas. However it must also be borne in mind that the pursuit of sustainable remediation should not be at the price of compromising the overall regeneration project (Holland et al. 2013).

Table 2 compares the concepts of sustainable remediation and sustainable brownfields regeneration, commenting on the degree of overlap between them on different thematic issues, based on the sustainable remediation documentation listed in Annex 1 of Supplementary material and the definitions provided by the various European brownfields projects. 
Table 2 Relations between sustainable remediation and sustainable brownfield regeneration. Sustainable remediation has been compared with sustainable brownfield regeneration, as the second one represents a sort of maximum level of land restoration (Swartjes et al., 2011)

\begin{tabular}{|c|c|c|c|}
\hline & Sustainable remediation & $\begin{array}{l}\text { Sustainable brownfield regeneration (and to some extent } \\
\text { redevelopment) }\end{array}$ & $\begin{array}{l}\text { Overlap: } \\
\text { Total (T) } \\
\text { Partial (P) } \\
\text { None (N) }\end{array}$ \\
\hline Addressed problem & Contamination. & Under use or abandonment of land. & $\mathrm{P}$ \\
\hline Descriptions & $\begin{array}{l}\text { Sustainable remediation: in a generic sense "the } \\
\text { achievement of a net benefit overall across a range of } \\
\text { environmental, economic and social concerns that are } \\
\text { judged to be representative of sustainability" (Bardos, } \\
\text { 2014). }\end{array}$ & $\begin{array}{l}\text { Sustainable brownfields redevelopment process: "a } \\
\text { voluntary effort that actively engages property owners, } \\
\text { developers, government agencies and the community in } \\
\text { conducting corrective action, economic evaluation, and } \\
\text { other actions to promote the long-term productive reuse of } \\
\text { a Brownfields property" (ASTM, 1984). } \\
\text { Sustainable brownfield regeneration: "the management, } \\
\text { rehabilitation and return to beneficial use of brownfields in } \\
\text { such a manner as to ensure the attainment and continued } \\
\text { satisfaction of human needs for present and future } \\
\text { generations in environmentally sensitive, economically } \\
\text { viable, institutionally robust and socially acceptable ways } \\
\text { within the particular regional context" (RESCUE, 2003). } \\
\text { Sustainable brownfield development is a "development that } \\
\text { has been produced in a sustainable way (e.g. in terms of } \\
\text { design, construction and participation processes) and } \\
\text { enables people and organisations involved in the end use of } \\
\text { the site to act in a sustainable way" (Williams and Dair, } \\
\text { 2005). }\end{array}$ & $P$ \\
\hline $\begin{array}{l}\text { Presence of } \\
\text { /Contamination } \\
\text { present }\end{array}$ & Always. & $\begin{array}{l}\text { Not always. Note: brownfields may include multiple } \\
\text { contaminated sites as well as totally uncontaminated sites. }\end{array}$ & $P$ \\
\hline Risk & Unacceptable given present or future land use. & Site is not necessarily suitable for its next use. & $\mathrm{P}$ \\
\hline Time frame & $\begin{array}{l}\text { Short to long. Often long for groundwater and short for } \\
\text { soil, especially in a redevelopment context. }\end{array}$ & $\begin{array}{l}\text { Short to long. More probably long, but once decision is made } \\
\text { to act, and the necessary resources secured, regeneration } \\
\text { can be quick. }\end{array}$ & $\mathrm{P}$ \\
\hline Area & $\begin{array}{l}\text { Small to large. Challenging areas can be affected by sites } \\
\text { that occupy complex geology, widespread recalcitrant } \\
\text { contaminants, and long, dilute plumes. }\end{array}$ & $\begin{array}{l}\text { Small to large. Challenging areas can be affected by sites that } \\
\text { occupy large areas (hectares) in a continuum or as a } \\
\text { multitude of small sites leading to fragmented land planning. }\end{array}$ & $\mathrm{P}$ \\
\hline
\end{tabular}




\begin{tabular}{|c|c|c|c|}
\hline $\begin{array}{l}\text { Potential stakeholders } \\
\text { involved }\end{array}$ & $\begin{array}{l}\text { 1. Potentially Responsible Parties } \\
\text { 2. Site owners } \\
\text { 3. Site neighbours } \\
\text { 4. Local authorities (town or city) } \\
\text { 5. Region and sub-regional government } \\
\text { 6. Regional and national regulators (environmental and } \\
\text { health protection) } \\
\text { 7. Local community groups (neighbourhood, districts) } \\
\text { 8. Public interest groups } \\
\text { 9. Developers/investors } \\
\text { 10. Technology providers } \\
\text { 11. Consultants } \\
\text { 12. Financiers } \\
\text { 13. Contractors (remediation) } \\
\text { 14. Insurers } \\
\text { 15. End-users } \\
\text { 16. Media } \\
\text { 17. Scientific community and research } \\
\text { (based on Rizzo et al., 2015) }\end{array}$ & $\begin{array}{l}\text { 1. Potentially responsible parties } \\
\text { 2. Site owners } \\
\text { 3. Site neighbours } \\
\text { 4. Local authorities (town or city) } \\
\text { 5. Region and sub-regional government \& spatial } \\
\text { planning departments } \\
\text { 6. Regional and national regulators } \\
\text { 7. Local community groups (neighbourhood, districts) } \\
\text { 8. Public interest groups } \\
\text { 9. Developers/investors } \\
\text { 10. Technology providers } \\
\text { 11. Consultants } \\
\text { 12. Financiers } \\
\text { 13. Contractors (remediation and construction) } \\
\text { 14. Insurers } \\
\text { 15. End-users } \\
\text { 16. Media } \\
\text { 17. Scientific community and research } \\
\text { (based on Rizzo et al., 2015) }\end{array}$ & $\begin{array}{l}\text { As stakeholder } \\
\text { categories almost T; } \\
\text { but sustainable } \\
\text { remediation implies } \\
\text { stakeholders with } \\
\text { dealing while } \\
\text { Environmental } \\
\text { Policy, land } \\
\text { regeneration those } \\
\text { dealing with land } \\
\text { planning policy. }\end{array}$ \\
\hline Policy context & $\begin{array}{l}\text { At international level, management of contaminated sites } \\
\text { and remediation procedures are usually addressed by } \\
\text { national, regional and local legislative frameworks. } \\
\text { Sustainable remediation has been only recently included in } \\
\text { some national and regional legislative frameworks, but } \\
\text { usually with only general indications/suggestions (e.g. in } \\
\text { the USA, Executive Orders } 13514 \text { and } 13423 \text { are enacted to } \\
\text { incorporate sustainability into federal activities, such as } \\
\text { remediation). } \\
\text { An exception is represented by Austria (Europe), where, } \\
\text { since 2012, the application of the MCEA tool for } \\
\text { sustainability options appraisal (Döberl et al., 2013) is } \\
\text { mandatory when requesting resources from the Austrian } \\
\text { National Remediation Fund. }\end{array}$ & $\begin{array}{l}\text { Sustainable brownfield regeneration has been included in } \\
\text { some national legislative frameworks and some documents } \\
\text { provided by national environmental protection agencies, } \\
\text { usually with general indications and suggestions. } \\
\text { Nevertheless, several EU Directives and USA policies (e.g. the } \\
\text { "Brownfields Law" that amended the Comprehensive } \\
\text { Environmental Response, Compensation, and Liability Act } \\
\text { (CERCLA or Superfund) on January } 11,2002 \text { (US EPA, 2012); } \\
\text { the Presidential Executive order } 12580 \text { have been enacted to } \\
\text { deal with aspects related with brownfield regeneration (e.g. } \\
\text { urban environments, soil, stakeholder engagement, resource } \\
\text { efficiency, circular economy and land use, structural funds, } \\
\text { state-aids, waste, water, groundwater, renewable energies, } \\
\text { nature and habitats). }\end{array}$ & $P$ \\
\hline
\end{tabular}


In the USA, there is a much greater overlap between the contaminated land and brownfield domains (Tang \& Nathanail, 2012). Brownfields (ASTM, 1984; US EPA, 2002) are defined as "real property, the expansion, redevelopment, or reuse of which may be complicated by the presence or potential presence of a hazardous substance, pollutant, or contaminant" (USEPA, 2002). Environmental concerns associated with a brownfields site are resolved in the context of financial limitations (e.g. limited remediation and redevelopment funds available) and social considerations (e.g. property reuse often times increases the quality of life of the local and surrounding communities) (Holland et al., 2013). Thus, the concepts of site assessment and cleanup of brownfields in the USA have a strong overlap with the concepts of sustainable remediation (Hadley and Harclerode, 2015).

Another concept subsidiary to sustainable remediation is "green remediation" (US EPA, 2008). As a concept, definitions of sustainable remediation encompass (but extend beyond) green remediation. Green remediation is intended to reduce the demand placed on the environment during clean-up actions and to conserve natural resources. It anticipates that the major decision-making elements setting the boundaries for remediation action, including economic and social considerations, have already taken place under the Comprehensive Environmental Response, Compensation, and Liability Act (CERCLA) National Contingency Plan (NCP) (US EPA, 2012). Hence, green remediation is about improving the environmental performance of the delivery of the remediation solution after the point at which a remedial solution has been selected (Bardos et al, 2013). A broad group of stakeholders in the United States worked over a four year period in the development of a voluntary standard (ASTM 2013) that could guide greener clean-up decisions at site remediation projects.

In the remainder of this paper, green remediation (as defined by the US EPA) and brownfield regeneration are discussed only in terms of how they are referenced or used in the various sustainable remediation frameworks reviewed.

The comparison of the international frameworks and related documents on sustainable remediation was carried out as shown in Figure 2, and was aimed at finding similarities and differences between the analysed frameworks as well as general trends.

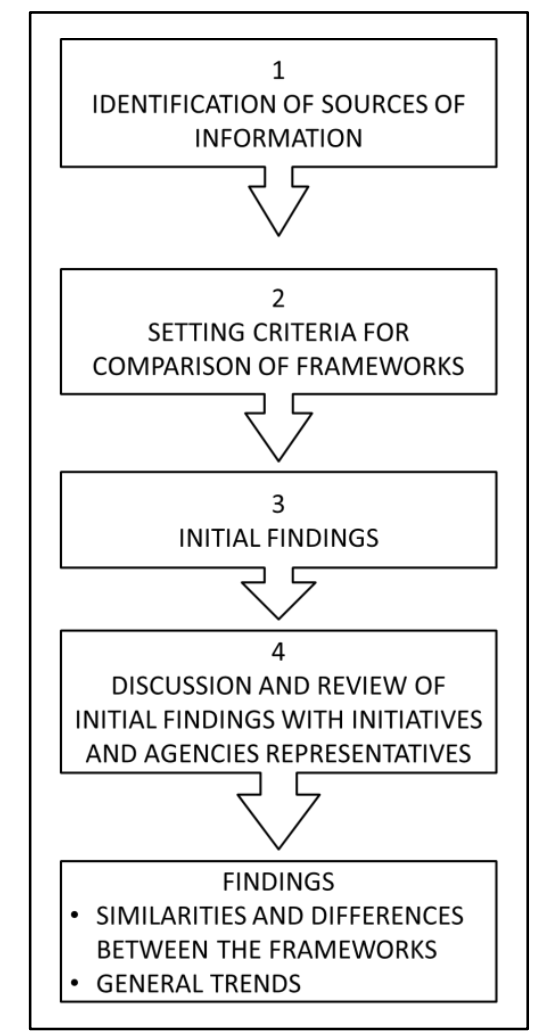

Figure 2 Comparison methodology and findings. 
The comparison criteria used are listed in Table 3, along with their respective definitions (in Italics) and information on how they have been used. This comparison methodology has been applied to documents directly produced by the listed initiatives, which are reported in Annex 1 of Supplementary material.

Table 3 Comparison criteria and respective definitions and indications for application.

\begin{tabular}{|c|c|}
\hline Comparison criterion & Definition and information on how criteria have been used \\
\hline Definition & $\begin{array}{l}\text { Formal statement of the meaning of sustainable remediation. } \\
\text { The analysis of the definitions of sustainable remediation provided by the initiatives allowed } \\
\text { some key themes to be identified, which represent key issues mentioned by the initiatives. } \\
\text { Key themes were further analysed dividing them in recurring themes and unique themes, } \\
\text { according to number of times they were mentioned in the definitions (i.e. recurring themes: } \\
\text { mentioned in more than one definition; unique themes: mentioned in only one definition). }\end{array}$ \\
\hline Principles & $\begin{array}{l}\text { Fundamental overarching concepts and values associated with sustainability, which should } \\
\text { always be considered when designing, implementing and reporting sustainable remediation } \\
\text { projects, where "sustainable remediation" is meant to be "elimination and/or control of } \\
\text { unacceptable risks in a safe and timely manner whilst optimising the environmental, social } \\
\text { and economic value of the work" (ISO, 2015). } \\
\text { The principles, stated and adopted by the initiatives, have been analysed using the same } \\
\text { method exploited to analyse definitions. Again, recurring themes and unique themes have } \\
\text { been identified. }\end{array}$ \\
\hline & $\begin{array}{l}\text { Conceptual scheme and/or concise text structured for describing and depicting core aspects } \\
\text { of the sustainable remediation process. } \\
\text { The initiatives' framework structures have been analysed considering key aspects emerging } \\
\text { from their design and contents. These consist of graphical aspects as well as key concepts or } \\
\text { issues. }\end{array}$ \\
\hline Context & $\begin{array}{l}\text { Circumstances, assumptions, facts that can influence the development of a framework. In } \\
\text { this paper the comparison analysis, conducted according to this criterion, aims to consider } \\
\text { how the issues "risk based land management", "sustainable remediation and sustainable } \\
\text { brownfield regeneration", "top-down versus bottom-up approach" and "quantitative versus } \\
\text { qualitative approach (assessment tiers)" are addressed by the initiatives. Issue categories } \\
\text { are based on common themes identified during review of the frameworks presented in } \\
\text { Annex } 1 . \\
\text { The context has been analysed checking where risk based land management was explicitly } \\
\text { discussed in the frameworks, how the initiatives perceive sustainable remediation in } \\
\text { relation to sustainable brownfield regeneration, if the proposed approach for remediation } \\
\text { appraisal is top-down or bottom-up, and, linked to the previous one, how quantitative and } \\
\text { qualitative approaches are suggested to be adopted. Indeed it is assumed that a top-down } \\
\text { approach often relies on quantitative approaches to support remediation appraisal, while a } \\
\text { bottom-up approach can benefit from a tiered approach, where qualitative methods are } \\
\text { also considered valuable for remediation appraisal. }\end{array}$ \\
\hline $\begin{array}{l}\text { Sustainability } \\
\text { assessment approach }\end{array}$ & $\begin{array}{l}\text { Approach/method suggested to assess sustainability. } \\
\text { In order to perform the comparison of the frameworks according to this criterion, a table- } \\
\text { based method has been adopted. For each framework, a general description of the } \\
\text { suggested assessment approach has been reported along with more specific information } \\
\text { on: } \\
\text { - how the framework suggests setting the objectives; } \\
\text { - } \text { what kind of decision the assessment approach is for (e.g. remediation, } \\
\text { - } \text { remediation in the wider domain of regeneration); } \\
\text { - } \text { how the initiative suggests defining boundaries; } \\
\quad \text { encompassed as "sustainability"); this is reflected also in the indicators used.* }\end{array}$ \\
\hline
\end{tabular}




\begin{tabular}{|c|c|}
\hline & $\begin{array}{l}\quad-\text { the methodology to be adopted. } \\
\text { * Indicator: single characteristic that can be compared between options to evaluate their } \\
\text { relative performance towards specific sustainable development concerns. Indicators need } \\
\text { to be measurable or comparable in some way that is sufficient to allow this evaluation } \\
\text { (CL:AIRE, 2010). }\end{array}$ \\
\hline $\begin{array}{l}\text { Terminology/ } \\
\text { Vocabulary }\end{array}$ & $\begin{array}{l}\text { List of specific technical words and expressions used or created ad hoc by an initiative to deal } \\
\text { with sustainable remediation. } \\
\text { Specific/technical words met in definitions and principles proved to be frequent (met more } \\
\text { than once), or infrequent. Frequent words have been analysed. }\end{array}$ \\
\hline $\begin{array}{l}\text { Engaging } \\
\text { stakeholders: }\end{array}$ & $\begin{array}{l}\text { Criterion to compare how different initiatives suggest to deal with stakeholders. Sub-criteria } \\
\text { are: "transparency in reporting to stakeholders", "effectiveness in reporting to stakeholders" } \\
\text { and "broad participation". } \\
\text { Recommendations provided by the different initiatives on how to deal with stakeholders } \\
\text { were compared. We considered the Bellagio Principles for assessing sustainable } \\
\text { development (IISD, 1996; as modified by Pinter et al., 2012) and we referred to: } \\
\text { - Principle } 5 \text { "Transparency"; } \\
\text { - Principle 6 "Effective communication"; } \\
\text { - Principle 7 "Broad participation". }\end{array}$ \\
\hline $\begin{array}{l}\text { Documentation } \\
\text { recordkeeping }\end{array}$ & $\begin{array}{l}\text { The management and archiving of information related with sustainable remediation } \\
\text { projects. } \\
\text { Suggestions provided by the different initiatives on how to manage and archive } \\
\text { documentation were analysed. }\end{array}$ \\
\hline Case studies & $\begin{array}{l}\text { Examples of applications of frameworks and approaches to specific sites. } \\
\text { Case studies are used to demonstrate that adopting effective sustainable remediation is } \\
\text { feasible and useful. Case studies represent a way of getting users involved, and encouraging } \\
\text { the use of sustainability tools by showing effective examples of how things have been done } \\
\text { in practice in practical applications. } \\
\text { Several initiatives on sustainable remediation offer on-line templates to encourage } \\
\text { stakeholders to provide information about their case studies. }\end{array}$ \\
\hline
\end{tabular}

This comparison has necessitated some shared understanding of a number of specific terms between the various participants. In this paper we have used the word framework to describe the main reference documents structuring, encompassing and supporting the core concepts that function to apply sustainable development principles to remediation. We have typically taken this as the document identified as the initiative itself as a "framework", "white paper", "roadmap" or other such overarching documents. Related documents describe supporting material developed by the initiatives. Examples of related documents include proposed indicator categories or case studies (see Annex 1 of Supplementary material). We have used the word "criterion" to refer to an expected component of a sustainable remediation approach, against which we can benchmark sustainable remediation frameworks. We have used the word "theme" to describe a particular idea or subject highlighted in one or more sustainable remediation frameworks. We have used the word "context" to describe the circumstances that form the setting for an event, statement, or idea, and in terms of which it can be fully understood; for example: the jurisdictional circumstances and prevailing policy and regulatory background; or the way in which sustainable development has been defined.

Initial findings were sent to the various initiatives being considered in this paper for debate and discussion (primarily by e-mail). Feedback was provided by members of: CL:AIRE, Common Forum, Environment Agency Austria, NICOLE, SURF-Italy, SURF-NL, SURF-UK, SURF, SURF-Colombia, SURF-ANZ, the ISO working group, and US EPA. Feedbacks provided by initiatives and agencies were incorporated into the discussions on similarities and differences among frameworks as well as general trends identified in the adopted 
approaches. The paper describes the outcomes following this engagement and does not separately present the preliminary findings these initiatives reviewed.

\section{Findings and discussion}

For each comparison criterion defined in Table 3, similarities and differences among the different international frameworks and related documents are reported and described.

\subsection{Definitions and Principles}

Ten definitions (or descriptions) of sustainable remediation from around the world are set out in Annex 2 of Supplementary material. These definitions show a high degree of consistency. Based on the exact wordings of the definitions, a number of recurring themes can be identified. These themes can be explicitly or implicitly mentioned. For instance the theme "Sustainability assessment/Assessment implied" is explicitly mentioned by Common Forum ${ }^{1}$, NICOLE and ITRC, while it is implicitly meant by SuRF-Italy, SURF-NL, SURFUK and SURF-ANZ within the expression "balanced decision-making process", where "balanced" implies the basis for assessment. Two themes are mentioned in nearly all definitions: decision making needs to be a balanced process of optimising benefits across the three elements of sustainability; and sustainable remediation needs to take account of all three elements (or pillars) of sustainability.

However, typically definitions do not stand alone, but are supported by a number of broader principles in a supportive text (See Annex 3 of Supplementary material). Table 5 lists the initiatives and the themes that occur more than once across the wordings of definitions and principles. Themes are listed according to the number of times they are mentioned by the initiatives. Table 5 indicates in each cell if the theme reported within the wordings is met:

- in the definition (D);

- in the principles (P);

- in the definition and in the principles (D\&P).

Table 4 lists themes identified more than once in definitions and principles along with an explanation.

Table 4 Themes identified more than once and explanation

\begin{tabular}{|l|l|}
\hline Theme & Explanation \\
\hline $\begin{array}{l}\text { Benefit optimisation/Better } \\
\text { remediation solutions }\end{array}$ & $\begin{array}{l}\text { The initiative highlighted this theme, meaning that optimisation of benefits } \\
\text { coming from the adoption of sustainable remediation is possible and in a } \\
\text { way recommended. }\end{array}$ \\
\hline $\begin{array}{l}\text { Human } \\
\text { health/Environmental } \\
\text { health/Risks - RBLM }\end{array}$ & $\begin{array}{l}\text { The initiative highlighted this theme, meaning that risk assessment is of } \\
\text { paramount importance in sustainable remediation. In other words, } \\
\text { sustainable remediation is risk-based. }\end{array}$ \\
\hline $\begin{array}{l}\text { Three pillars/elements of } \\
\text { sustainability }\end{array}$ & $\begin{array}{l}\text { The initiative highlighted this theme, confirming the importance of all the } \\
\text { three sustainability pillars and the commitment to consider them. }\end{array}$ \\
\hline $\begin{array}{l}\text { Sustainability } \\
\text { assessment/Assessment } \\
\text { implied }\end{array}$ & $\begin{array}{l}\text { The initiative wanted to draw attention of readers on the fact that } \\
\text { sustainable remediation is based on an assessment process. }\end{array}$ \\
\hline Decision making process & The initiative highlighted this theme, meaning that decision-making based \\
\hline
\end{tabular}

\footnotetext{
${ }^{1}$ Note the COMMON FORUM definition is taken from its shared publication, joint position statement, with NICOLE (Common Forum and NICOLE, 2013).
} 


\begin{tabular}{|c|c|}
\hline & $\begin{array}{l}\text { on sustainability principles represent a win-win factor in sustainable } \\
\text { remediation. }\end{array}$ \\
\hline Transparency & $\begin{array}{l}\text { The initiative highlighted this theme, meaning that transparency is a } \\
\text { valuable factor to achieve sustainable remediation. }\end{array}$ \\
\hline Stakeholders & $\begin{array}{l}\text { The initiative highlighted this theme, meaning that involving stakeholders } \\
\text { is important for achieving effective sustainable remediation. }\end{array}$ \\
\hline $\begin{array}{l}\text { Emphasis on technical } \\
\text { environmental issues and } \\
\text { actions }\end{array}$ & $\begin{array}{l}\text { The initiative highlighted this theme, meaning that a focus on technical } \\
\text { environmental issues and actions is needed. }\end{array}$ \\
\hline Long term vision & $\begin{array}{l}\text { The initiative highlighted this theme, meaning that adopting a long term } \\
\text { vision can be beneficial to ensure long standing results. }\end{array}$ \\
\hline $\begin{array}{l}\text { (Contaminated } \\
\text { Management }\end{array}$ & $\begin{array}{l}\text { The initiative highlighted this theme, meaning that sustainable } \\
\text { remediation can be part of a wider process. }\end{array}$ \\
\hline Sound science & $\begin{array}{l}\text { The initiative highlighted this theme, which is significant to make the } \\
\text { assessment results consistent. }\end{array}$ \\
\hline Use of indicators/metrics & $\begin{array}{l}\text { The initiative highlighted this theme, in a way recommending a tiered } \\
\text { assessment approach. }\end{array}$ \\
\hline Complying with regulations & $\begin{array}{l}\text { The initiative highlighted this theme, meaning that the legal framework is } \\
\text { the unavoidable basis where to start the assessment from. }\end{array}$ \\
\hline $\begin{array}{l}\text { Judicious limited resources } \\
\text { use/use of resources }\end{array}$ & $\begin{array}{l}\text { The initiative highlighted this theme, meaning that resources, like land, are } \\
\text { limited and this has to be beard in mind during sustainable remediation. }\end{array}$ \\
\hline Record keeping & $\begin{array}{l}\text { The initiative highlighted the importance of this theme to make the } \\
\text { assessment process always traceable and verifiable. }\end{array}$ \\
\hline Safe working practices & $\begin{array}{l}\text { The initiative highlighted the importance that workers adopt safe working } \\
\text { practices during remediation works. }\end{array}$ \\
\hline $\begin{array}{l}\text { Emphasis on socio- } \\
\text { economic } \\
\text { factors/community impacts }\end{array}$ & $\begin{array}{l}\text { The initiative highlighted the importance of considering the economic and } \\
\text { social pillars to properly manage potential impacts on community. }\end{array}$ \\
\hline
\end{tabular}

Almost all or even all themes could occur in initiatives' frameworks reviewed, if the entire document is considered or in an implicit. However, this analysis focused specifically on what was written, i.e. the wordings used in definitions and principles, as defined in Table 4. Therefore, themes not identified in frameworks compared in Table 5 do not imply that those themes are not reflected in the framework, rather they are not explicitly present in the actual wording of definition and principles. We feel this a valid approach, as for many (if not most) practitioners, this written information will be the point of entry and main point of reference for the various sustainable remediation frameworks published. 
Table 5 Themes mentioned more than once in definitions and principles, and listed according to the times they are mentioned.

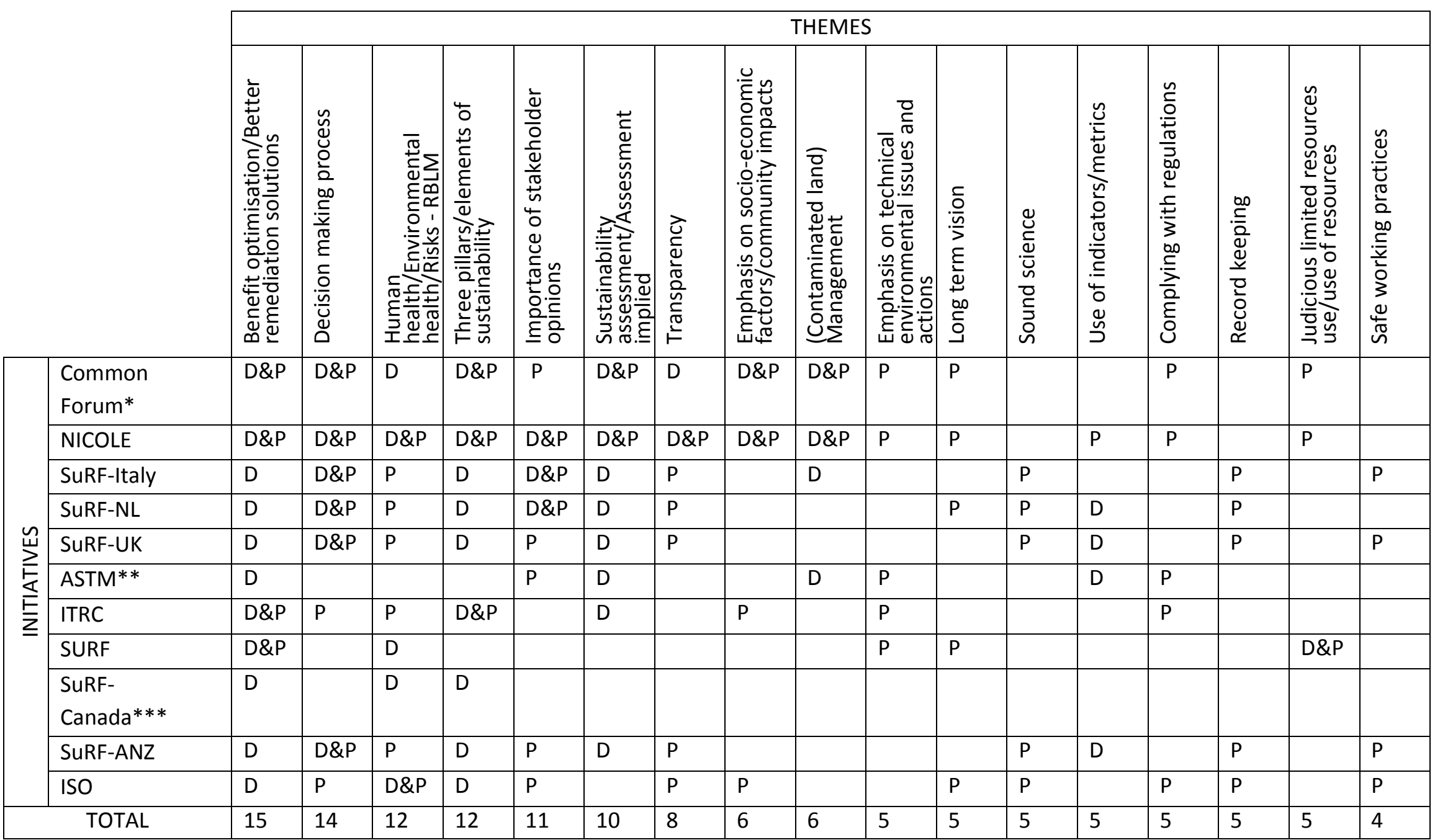

* Note the COMMON FORUM definition and principles are taken from its shared publication with NICOLE (Common Forum and NICOLE, 2013).

**The ASTM E2876-13 Standard does not include a set of principles.

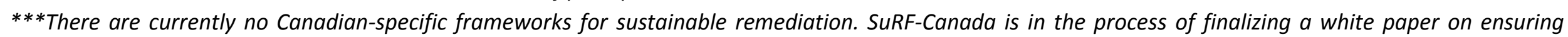
optimal remediation project outcome. 
The theme of "Benefit optimisation/Better remediation solutions" refers to the idea that applying sustainable remediation should lead to remediation outcomes with, overall, an enhanced overall level of benefit (or reduced level of detriment) across a broad range of sustainability criteria. This idea is mentioned by all initiatives in their definitions. However, is only explicitly mentioned in the principles of four initiatives' (Common Forum, NICOLE, ITRC, and SURF).

All of the following five broad themes are mentioned in the definitions/principles of most frameworks: importance of balanced decision-making based on sustainability principles, pre-eminence of risk assessment as the basis of deciding the need for remediation, the three elements of sustainability, importance of stakeholder opinions, and sustainability assessment as basis for sustainable remediation. These themes represent the following ideas:

- A balanced approach to decision making is the idea that a wide range of sustainability criteria are considered in decision making, with no factor having undue influence (although weightings of importance might be considered, as long as this is done in an explicit and transparent way).

- Remediation decision-making is predicated on the removal of unacceptable levels of risk to human health, water, ecology or other receptors of concern. The removal of these risks remains the central aim of a remediation project and should not be diminished in any way by factoring removal against other criteria such as cost, resource usage etc. Sustainable remediation is intended to find the optimal approach to achieving the necessary risk management which maximises wider benefits and minimise detriments (discussed in more detail in Section 3.3).

- Sustainable development encompasses three elements: society, environment and economy, otherwise known as the three pillars of sustainability: "people, planet and profit".

- Stakeholder involvement is crucial to achieve successful sustainable remediation.

- Sustainability assessment: some process of comparison of remediation options is necessary to identify the most sustainable potential approaches, this process is known as sustainability assessment.

The following themes are incorporated in the principles of a number of frameworks:

- An "emphasis on technical environmental issues and actions" as opposed to the social and economic elements of sustainable remediation was evident in the text of documents. ITRC (2011b), SURF (2009) and ASTM (2013) definitions and principles highlighted environmental issues, activities and consequential impacts that can occur during a remediation process (e.g. energy consumption, release to the environment). This tendency could be explained by the fact that, in the USA, green remediation has played a significant role in contaminated land management as regulated by the US-EPA, under CERCLA (US EPA, 2012), which considers it "as the practice of considering all environmental effects of clean-up actions and incorporating options to minimize the environmental footprints of clean-up actions" (US EPA, 2011).

- A "Long term vision" describes the idea that sustainable remediation outcomes should be beneficial in the long term and are part of a longer term basis for understanding the success of remediation measures, and is explicit in the documents of Common Forum, NICOLE, SURF-NL, SURF and ISO;

- "Sound science" is the idea that sustainability assessment needs to be based on robust evidence and technical concepts that are transparent, reproducible and can meet expert technical peer review scrutiny. The need for a sound science basis is mentioned by in the various European Union SuRF organisations, SURF-ANZ, and ISO. "Complying with regulations" is acknowledged by ISO, COMMON FORUM, ASTM, and ITRC.

Besides the themes described in Table 4, there are some unique points made in the definitions and principles of few frameworks only: the importance of communication with wider stakeholder interests; taking a 'bottom-up' approach as described below, and the sharing of experiences through case studies for NICOLE (2012); the consideration of local and larger community for SuRF-Canada; and addressing unacceptable risk in a "timely manner" for ISO (2015). NICOLE also highlights the need to build trust 
between stakeholders and for considering socio-economic factors in sustainable remediation (NICOLE, 2012).

\subsection{Framework structures}

The documents reviewed typically offer guidance on how decision-making should be structured showing the decisional process by means of a diagram, a flowchart, or a scheme with for instance shapes, arrows and symbols. In this paper these schemes are referred as "framework structures". Examples of these are given in Annex 4 of Supplementary material. We have separated out a number of aspects occurring in these framework structures, defined in Table 6. We have then mapped the frameworks where these aspects appear, in Table 7.

Table 6 Framework structure aspects and explanations.

\begin{tabular}{|c|c|}
\hline Aspect & Explanation \\
\hline Graphic representation & $\begin{array}{l}\text { The document provides an overarching graphical representation } \\
\text { (framework structure) to support readers in visualising the process } \\
\text { of achieving sustainable remediation. }\end{array}$ \\
\hline Sustainability & $\begin{array}{l}\text { The sustainability concept explicitly includes all three elements } \\
\text { (pillars) of sustainability. }\end{array}$ \\
\hline Remediation option appraisal & $\begin{array}{l}\text { The sustainable remediation framework is underpinned by } \\
\text { comparison of different available options. }\end{array}$ \\
\hline Stakeholder engagement & $\begin{array}{l}\text { Involving stakeholders is regarded as important for achieving } \\
\text { effective and reliable sustainable remediation decisions. }\end{array}$ \\
\hline $\begin{array}{l}\text { Sustainable decisions early in the } \\
\text { process }\end{array}$ & $\begin{array}{l}\text { Early consideration of sustainable remediation in project } \\
\text { development, e.g. as early as land-use planning, is seen as leading to } \\
\text { potentially greater sustainability gains than solely considering } \\
\text { sustainable remediation as a means of determining best remedial } \\
\text { approach for pre-finalised remediation objectives. }\end{array}$ \\
\hline $\begin{array}{ll}\text { Sustainable } & \text { Remediation } \\
\text { contextualisation } & \end{array}$ & $\begin{array}{l}\text { Emphasising the role of sustainable remediation as part of wider } \\
\text { regeneration projects. }\end{array}$ \\
\hline End-use concerns & $\begin{array}{l}\text { The framework identifies the particular importance of considering } \\
\text { concerns of end-users that will live, work in, and in general use the } \\
\text { remediated site in stakeholder engagement processes. }\end{array}$ \\
\hline $\begin{array}{l}\text { Risk assessment } \\
\text { management }\end{array}$ & $\begin{array}{l}\text { Remediation decision-making is predicated on the removal of } \\
\text { unacceptable levels of risk to human health, water, ecology or other } \\
\text { receptors of concern. In other words, sustainable remediation is } \\
\text { risk-based. }\end{array}$ \\
\hline Life cycle concept & Life cycle thinking should be applied to sustainable remediation. \\
\hline Focus on green aspects & A focus on environmental aspects is considered necessary. \\
\hline $\begin{array}{l}\text { Sustainable conceptual site } \\
\text { model }\end{array}$ & $\begin{array}{l}\text { The importance of the conceptual site model as a tool that drives } \\
\text { the risk assessment and sustainable remediation options appraisal } \\
\text { processes. }\end{array}$ \\
\hline
\end{tabular}


Table 7 Table reporting the aspects considered by each initiative that provides a framework structure.

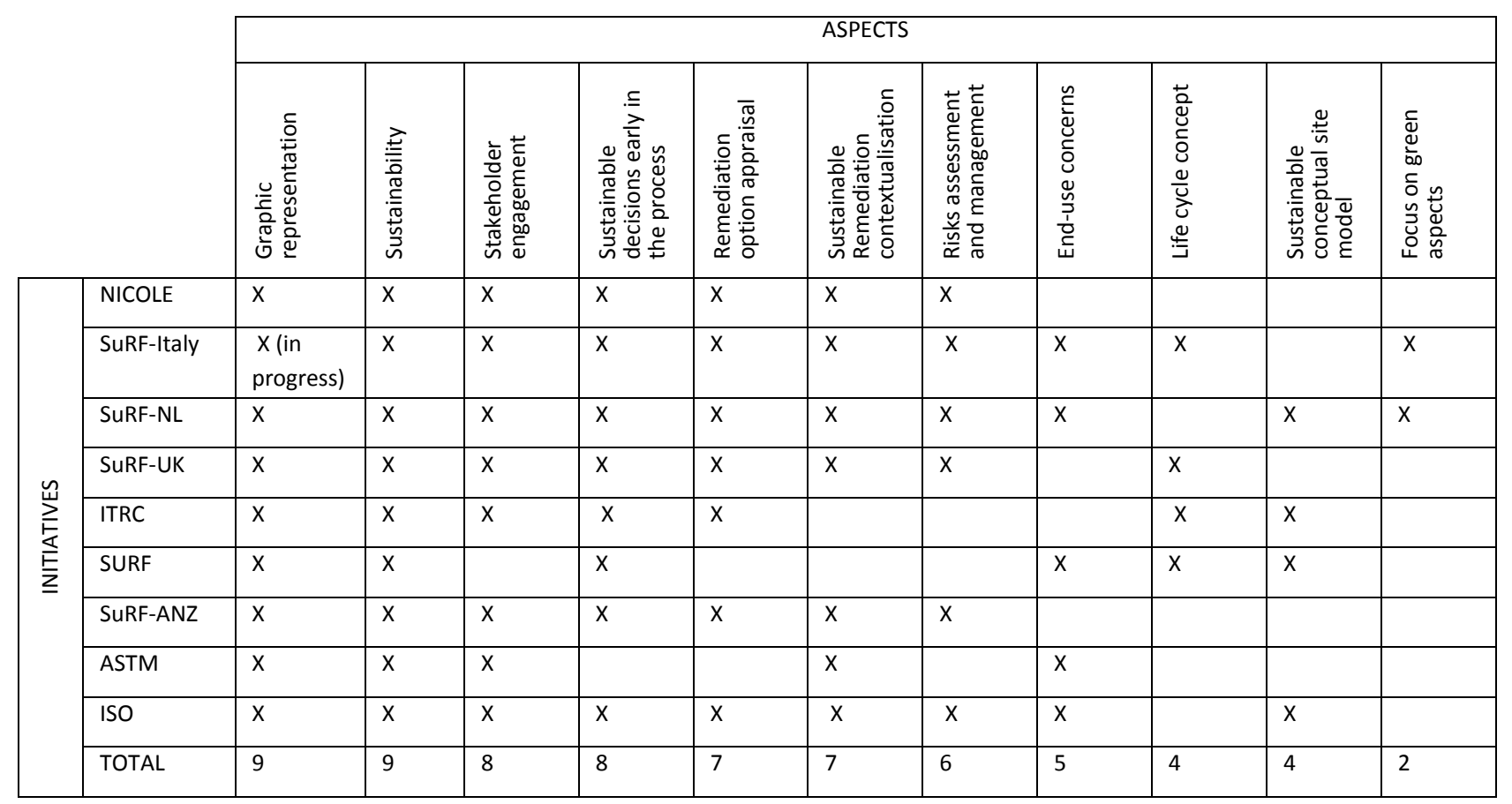

Table 7 does not include the Common Forum or SuRF-Canada. Common Forum is not reported in this table because it has not issued a formal sustainable remediation framework document. This is because Common Forum aims to facilitate its member countries to have their own frameworks in direction of sustainable remediation principles, rather than have a specific framework for the forum itself. There is currently no specific Canadian sustainable remediation framework document. However, SuRF-Canada is in the process of finalizing a white paper on ensuring optimal remediation project outcome.

Perhaps understandably there is a general tendency among the frameworks reviewed to provide a graphic representation for sustainable remediation decision-making processes. The various framework structures reinforce their respective definitions and principles. These are linked to management and technical aspects in the frameworks, taking into account their jurisdictional context. These structures are all reproduced in Annex 4 of Supplementary material. The number of stages in the decision-making described varies.

NICOLE (2010) identifies four stages ("regional/locality", "site(s) or project(s)", "remedy selection", and "remedy process"). SuRF-Italy (in progress) provides a flowchart where the remediation options appraisal is part of the overall sustainability management and, eventually, brownfield regeneration process. SuRF-UK (CL:AIRE, 2010) focus on two main stages ("Stage A - Plan/Project design" and "Stage B - Remediation Implementation").

ITRC, in the USA, (2011b) suggests a five stage process: "evaluate/update conceptual site model", "establish goals", "stakeholder involvement", "select metrics and GSR evaluation level", and "record GSR efforts". The ITRC guidance also includes a complementary implementation flowchart consisting of these stages "identifying GSR options", "performing GSR evaluations", "implementing GSR approaches", and "monitoring, tracking, and documentation". The two flowcharts combined illustrate the ITRC GSR framework. SURF, in the USA, (2011) depicts the sustainable remediation decision-making process both as a linear process and as an iterative process, shown as a spiral, to better represent routinely incorporating sustainability throughout the remediation project life cycle. SURF suggests this better shows how sustainability of remediation implementation is continually evaluated and optimised for the benefit of all stakeholders. ASTM (2013) provides a six-step flowchart for best management practice selection and implementation in order to encourage users to incorporate sustainable elements into clean-up projects. 
ASTM also provides a structure that describes the relationships between the three pillars of sustainability across several specific considerations: energy, local community vitality, efficiencies in clean-up \& cost savings, and the proposed best management practices.

SuRF-ANZ (2011) and ISO (2015), in line with SURF-UK, provides a flowchart where the decision-making process is divided in two main stages, i.e. plan/project design and remediation implementation.

Focusing on the descriptive aspects within the framework structures, NICOLE (2010), SuRF-Italy (in progress), SURF-UK (CL:AIRE, 2010), ITRC (2011b), SURF (2011) and ISO (2015) provide stakeholders with explicit indications on when and how to apply sustainability in different phases of planning and project management decision making and implementation.

NICOLE (2010), SuRF-Italy (in progress), SuRF-NL (2015), and SURF-UK (CL:AIRE, 2010) framework structures all embed sustainable remediation in a wider decision making and planning context, where sustainable decisions should be taken as early as possible to enhance the opportunities for combining remediation with wider development-driven sustainability goals, and so achieve a better overall sustainability performance. The NICOLE Road Map (2010) frames remediation design, from a temporal point of view, after spatial planning and project design/site use. The NICOLE Road Map (2010) and SuRF-UK (CL:AIRE, 2010) framework both suggest that remediation design should be considered as soon as possible in project planning to maximise sustainability gains. The relationship between sustainable redevelopment and sustainable remediation has also been explored and confirmed in some detail by Holland et al. (2013). It should be noted that other framework documents also stress the importance of considering and incorporating sustainable remediation practice early in the project planning (e.g., ITRC, SURF, and ASTM), but do not explicitly link these considerations to broader redevelopment goals.

\subsection{Context}

Context influences how the initiatives develop their frameworks and how they suggest implementing sustainable remediation. Depending on the jurisdiction and participating stakeholders, initiatives can differently perceive and address: a) risk-based approaches, b) the relationship between sustainable remediation and brownfield regeneration, c) top-down versus bottom-up approaches to sustainable remediation, as defined below, and d) quantitative versus qualitative approaches to assess sustainable remediation. The following provides a discussion on how initiatives' frameworks are influenced by these contexts.

\section{Risk-based approaches}

The majority of frameworks align sustainable remediation with the use of risk assessment to determine the need for and extent of remediation, and what outcomes would be deemed as acceptable. For example, the COMMON FORUM and NICOLE (2013) firmly link sustainable remediation to the principles of Risk-Based Land Management" (CLARINET, 2002). SURF-UK (CL:AIRE, 2010) links sustainable remediation to the riskbased approach for managing land contamination already in place in the UK, which is based on protecting human health, the environment and other specified receptors. The SuRF-UK framework has been developed to supplement the existing risk-based approach by addition of sustainability considerations, and so support a proportionate and risk-based approach". The other SuRF groups in Europe share this position. ISO $(2015$, p. 4) emphasises that "Sustainable remediation is about how to manage risks that merit intervention; it is not an excuse for doing nothing when you have such risks."

The consideration of risk in US-based frameworks is primarily based on the "the overall protection of human health and the environment" which is a key criterion in the EPA's National Contingency Plan (NCP) (40CFR300.430(e)(9)) for evaluating remediation options for a contaminated site. The ASTM E2876-13 Standard aligns itself with ASTM E2081 Guide for Risk-Based Corrective Action (RBCA), "a process enabling decisions to be made based on the risks posed to human health and the environment (ASTM International, 2010)". The SURF Framework (2011) acknowledges that risks associated with site worker health and safety and the community (e.g., truck accidents on the open road) are "not given proper consideration in 
remediation decisions". The SURF Framework (2011) also presents methodologies to conduct a risk-benefit analysis of proposed environmental management options. An example is Net Environmental Benefit Analysis (NEBA) to assist in quantifying and comparing ecosystem service impacts from proposed remediation and redevelopment scenarios. The NEBA quantified for each proposed cleanup scenario is based on the changes to cost and predicted changes in risk associated with the ecosystem service impacts considered in the evaluation.

ITRC (2011b) clearly states that "the ultimate goal of remediation is to protect human health and the environment. To meet this goal, many remedies have been focused on site-specific risks". This statement is in alignment with EPA's NCP. GSR approaches facilitate reduction of adverse secondary impacts of risk management actions on the environment and reduce the cost and time needed to achieve remediation goals.

The pre-eminence of risk-based land management is also recognized by ISO (2015).

\section{Sustainable remediation and brownfield regeneration}

The Common Forum and NICOLE (2013), SuRF-Italy (2014), SURF-UK (CL:AIRE, 2010), ASTM (2013), ITRC (2011b) SURF $(2011,2013)$ and ISO (2015) all explicitly provide a nexus between sustainable remediation and brownfields use.

While the brownfield sustainable redevelopment context is seen as broader than the sustainable remediation one, a nexus between these two domains is clearly recognised as important in the majority of sustainable remediation frameworks. As shown on Table 1, there are several similarities among the two domains, and they complement each other with the overarching objective of achieving a net benefit across environmental, economic and social concerns. In the US, the link between these domains assists in highlighting the successful outcome of incorporating sustainable practices in remediation (Hadley and Harclerode, 2015). However, the pursuit of sustainable remediation at a brownfield does not come at the expense of overall sustainable redevelopment (cf. Holland et al 2013 \& HOMBRE 2014).

\section{Top-down versus bottom-up approach / Sustainability assessment approach (quantitative versus qualitative)}

"Top down" decision-making describes a situation where key sustainability criteria and the methodologies for assessing and combining them are pre-selected or pre-defined in a prescriptive way in an overarching sustainability assessment procedure or approach. "Bottom-up" decision making describes a situation where the individual stakeholders associated with a particular project have at least some flexibility in identifying and agreeing the sustainability criteria and assessment methodology that they feel is most relevant to their particular project's circumstances. In this case the guidance offered by a framework document is more descriptive.

European initiatives, such as SuRF-UK and SuRF-NL, share a tendency to recommend combining compliance to regulatory mechanisms with a bottom-up approach to sustainability assessment and decision making. A tiered approach to assessing sustainable remediation is recommended, where the entry level of sustainability assessment is qualitative, and assessment progresses sequentially through semi-quantitative and quantitative tiers only where there is a strict need for a more quantitative approach. The rationale is to optimise the effort and cost of sustainability assessment and make shared decisions as soon as reliable information is available. A tiered approach also helps ensure that effort on any more detailed assessment is focussed on the specific criteria where agreement has not been reached at a lower tier (Bardos et al., 2016). A bottom up approach also recognises that not all stakeholders find quantitative methods robust, reliable or transparent (Hunt and Smith, 2015). In particular, not all sustainability criteria are seen as reliably quantifiable or monetisable for all stakeholders. 
Regulatory green remediation policies and guidance from the USA (including the US EPA green remediation guidance) encourage organisations to focus particularly on taking action to reduce the environmental footprint of the clean-up process itself (i.e., chosen remediation technology). EPA technical guidance suggests the use of quantitative analysis of the environmental footprints at more complex projects, to better discern which activities are significant footprint contributors and in that way better target footprint reduction measures.

The US SURF (2011), ITRC (2011b), and ASTM (2013) frameworks tend to be more prescriptive and place a greater emphasis on conducting quantitative evaluations when comparing different remediation options for a project. However, all three frameworks also encourage a bottom-up approach to defining and weighing sustainability objectives by promoting the engagement of stakeholders during this process. SURF (2011) and ITRC (2011b) frameworks also acknowledge the use of semi-qualitative/quantitative assessment tools (e.g., rating and scoring systems) and qualitatively evaluating sustainability impacts of incorporating best management practices. The ITRC framework is based on tiered approach: Tier 1 identifies, implements, and qualitatively evaluates best management practices; Tier 2 combines the selection of BMPs with a quantitative footprint evaluation; and Tier 3 combines the selection of BMPs with an extensive quantitative life cycle assessment.

The US sustainability assessment case studies reviewed (see Section 3.6) tend towards a top-down approach for sustainability assessment, which is in line with a more intensive centralised effort for quantitative parameters.

\subsection{Sustainability assessment methodology}

Performance of a sustainability assessment for evaluating proposed alternative options of remediating a site is a necessary a part of the decision-making and management process of remediation, and, as such, is widely discussed in the framework documents. We have compared the sustainability assessment methodology presented by the different frameworks across several broad components as described in the SuRF-UK framing guidance (CL:AIRE, 2010), NICOLE (2010) and Bardos et al. (2011):

- Objectives setting including the rationale for the sustainability assessment, the decision being supported, how the outcomes will be used and the project options being compared

- Boundary setting to ensure like will be compared with like, in particular the system boundary, the level of detail to be included in analyses, boundaries concerned with distance and time

- Setting the scope of the assessment, i.e. the range of sustainability effects to be considered, for example as decision making criteria.

- Methodological approach, how individual considerations will be combined / aggregated into an overall assessment of sustainability (whether qualitative, semi-quantitative or quantitative).

- Additional measures, for example the use of sensitivity analyses to explore the reliability of assessments.

There is broad consensus about the importance of effective objective setting, clear boundary setting and the usefulness of taking a tiered approach to sustainability assessment (see Annex 5). ITRC, SURF and SuRFUK frameworks discuss the importance of defining the spatial and temporal extent of the sustainability assessment scope, consideration of cradle-to-grave impacts, and the need to account for impacts beyond the physical boundary of the site. NICOLE (2010, 2012), SuRF-Italy (2014), SURF-UK (CL:AIRE, 2010), ITRC (2011a), ASTM (2013), SURF (2011) and ISO (2015) all emphasise taking tiered approaches.

There is greater divergence in how the scope of sustainability is considered and the exact nature of sustainability assessment methodology. SuRF-UK emphasises the usefulness of sensitivity analyses to test the robustness of assessments, for example to differences in opinion between different stakeholders involved in the sustainability assessment discussions. The USA framework documents tend to place a greater emphasis on quantitative sustainability assessment methodologies which has a bearing on the 
sustainability criteria which can be actively considered for two reasons. Firstly, there is an absolute restriction because some criteria may be very hard to quantitatively evaluate, for example the effect on the aesthetics of a landscape or built environment. Secondly, there is a practical restriction because quantitative evaluations tend to require greater effort so they are more costly, hence the overall range of considerations may be reduced or the assessment is not performed. Additionally, a reliance on "standard" methodologies such as life cycle assessment (LCA) or carbon footprint analysis excludes significant sustainability criteria. For example, LCA does not usually encompass soil functionality, and footprint measures one (albeit important) environmental criterion only. Hence, even though there are common tendencies in the approaches, the sustainability assessment approach proposed by one initiative for a particular context may not always be transferable to another (Bardos, 2014). However, this analysis should not be seen as absolute. A counter emphasis in US framework documents is that they also highlight the importance of a tiered approach. Furthermore, none of the guidance documents reviewed are obligatory, all are advisory. This means in any location particular organisations may decide that they prefer a more qualitative or a more quantitative approach. What is important is that the impact of this choice on the scope of sustainability considerations included is well understood.

Initiatives referenced, as part of this paper, continually collaborate on addressing knowledge gaps associated with sustainability assessment methodology. A common knowledge gap among the initiatives that was recently addressed was identifying comprehensive and transparent methods to evaluate the social sphere of sustainable remediation. The initiatives defined ten main societal impact categories based on review of the frameworks. As well as, identified several social impact assessment techniques to evaluate social impacts of remediation activities (Harclerode et al., 2015).

\subsection{Provision of Terminology/Vocabulary}

A number of documents provide glossaries or lists of definitions of terms used: NICOLE (2012), ISO (2015), ASTM (2013), SURF-UK (CL:AIRE, 2010), see Annex 6 of Supplementary material. Within other documents descriptions of terms tend only to be explained implicitly, or as the term first appears in the text. These definition of terms used are quite consistent across documents and no further discussion is necessary.

\subsection{Case studies}

Annex 7 collates a number of case studies (Table 1) and case study templates issued by NICOLE, SuRF-Italy, SuRF-UK and SURF. The number of case studies published (so far) by NICOLE, SURF-Italy, SURF-UK, ITRC and SURF is $8,10,3,10$ and 12, respectively. All of the case studies attempt to consider all three elements of sustainability but with varying degrees of rigour and transparency.

NICOLE, SURF-Italy, SURF-UK and SURF provide an on-line template to assist experts involved in sustainable remediation projects to provide specific, standardised and comparable information about them. SuRF-Italy and SURF-UK templates require information to identify and describe the site and the context, and to present the sustainability assessment process and related outcomes. The SURF template explicitly requires further information, such as the Regulatory Programme, site end use, key stakeholders, best management practices, metrics, tools and project contact.

24 individual case study documents were reviewed (data based on activities carried out until April 2015): 17 are related to remediation processes, while six are related to remediation processes in the context of wider regeneration projects, and one is about the development of a policy (ITRC, 2011b).

While most of the case studies report information on the approach used for option appraisal, some of them present the approach used for post-selection assessment to optimise performances of technologies already chosen and in use. Some have had to be written retrospectively and some are based on mind-game stakeholder engagement.

In general, the sustainability assessment approaches adopted more often are the following: BMP evaluations, carbon calculations, footprint calculations and life cycle assessment as well as risk-based 
approaches and multi criteria decision analysis. These should be preferably used in synergy and should be supported by expert judgements and stakeholders' contributions.

Some information is available on the range of considerations currently being incorporated in sustainability assessment case studies. The Environment Agency Austria has made an analysis of case studies (options appraisals) based on 22 contributions to the " 3 rd International Conference on Sustainable Remediation" held in Ferrara, Italy in 2014. It can be shown that contrary to secondary environmental effects (impacts such as greenhouse gas emissions, waste generation, water consumption, energy demand), which are considered in almost all case studies, only a minority of case studies are counting for primary environmental effects (i.e. benefits such reducing the risks or the amount of contaminants), which may result in biased ranking of options. The application of "off-the-shelf" methods, mostly LCA-based software tools, which are not designed to include benefits, can be identified as one of the causes for this observation. It is to be hoped that more holistic and tailored approaches become the norm as consultancy practice in sustainable remediation consideration matures (Döberl and Müller-Grabherr, 2015).

\subsection{Engaging stakeholders}

Stakeholder involvement is considered a key requirement for the optimal application of sustainability to remediation projects (Cundy, et al., 2013) and this is a key theme in the definitions and principles proposed by the analysed frameworks (see Table 5 ).

Common Forum and NICOLE (2013), in line with the Bellagio principles of "Transparency", "Effective communication" and "Broad participation", state that "stakeholders should be involved, and their interests [should be] considered in the decision making process, when, how and to what extent remediation meets also overall societal interests" and since "sustainability cannot be quantified in absolute terms, stakeholder engagement is crucial to ensure that a sustainability assessment minimises uncertainties in its consideration of project-specific issues and concerns, and allows stakeholders to provide their perspectives on the balance of potential impacts and benefits".

NICOLE, in its Road Map (2010), invokes stakeholders even when defining what a sustainable remediation project is (see Annex 2). It also states that sustainability assessment aims to build trust and consensus among stakeholders and "the earlier stakeholders consider sustainability principles, the more opportunities there are to improve sustainable outcomes and so provide greater benefit". According to NICOLE, stakeholders should be involved in the selection of key performance indicators.

SURF-UK (CL:AIRE, 2010) goes beyond the normative reasons of involving stakeholders stating it is important involving them for three reasons: 1) stakeholders can provide crucial information about particular aspects of sustainability; 2) consultative processes improve transparency and robustness of decisions; and 3) engaging stakeholders is part of good governance.

Also SURF (2011), ASTM (2013) and ISO (2015) align their recommendations to the Bellagio principles and recognise that encouraging collaborative participation with stakeholders is a key objective in sustainability assessment. Moreover, they recognise that social equity and considerations for stakeholders' perspectives, potential problems, and concerns should be taken seriously throughout the remediation process.

In the regulatory context of USEPA, when the CERCLA, also known as Superfund was passed in 1980, it was structured to ensure that the people whose lives were affected by abandoned hazardous wastes, and EPA's actions to clean them up, would have an effective voice in the entire clean-up process. The Superfund program has since developed a very robust community involvement protocol to ensure communities have a say in the decision making process at Superfund sites. The protocol has been codified in the Superfund Community Involvement Handbook ${ }^{2}$ (US EPA, 2015).

\footnotetext{
${ }^{2}$ http://www.epa.gov/superfund/community/policies.htm
} 


\subsection{Documentation and recordkeeping}

Most of the frameworks reviewed emphasise the importance of management of documentation and record keeping (see Annex 8).

NICOLE (2011) states that all stakeholders, and especially non-specialist participants, must be able to keep track of the decision making process. Furthermore, NICOLE states that record keeping should cover all steps of the Road Map from the setting of initial objectives onwards.

SURF-UK (CL:AIRE, 2010) considers record keeping to be of high importance and this is demonstrated by the fact that this issue is addressed in one of the adopted principles (See Annex 3). SuRF-Italy (2014) directly refers to SURF-UK recommendations.

ITRC (2011b) emphasises the value of documentation focusing on the importance of record keeping throughout the project and on the importance that the sustainability assessment approach should be understood and results verified. ITRC recommends that constraints or barriers should also be reported and that the level of communication should be tailored according to the stakeholders the documentation is presented to.

SURF (2011) states that up-to-date documentation ensures transparency and makes clear how the framework is applied. SURF also provides a bulleted list of issues that should be documented in a sustainable remediation project (see Annex 8).

SURF-ANZ (2011) directly refers to SuRF-UK recommendations.

Finally, ASTM (2013) states that it is important to document the activities and evaluations performed while implementing the guide in order to demonstrate the sustainable benefits through open communication and transparency. ASTM dedicates an entire section of the standard to this issue.

\section{Conclusions and recommendations}

The sustainable remediation initiatives reviewed have developed frameworks, standards, white papers, indicator sets, case studies collections and other related documents and share an international dialogue to further develop sustainable remediation concepts. There is a high level of consensus on definitions, descriptions and underpinning principles in these documents, indicating a widespread shared understanding of what sustainable remediation is across countries and professional stakeholder categories (regulator, site owner, service provider, etc.). The main areas of consensus are in definitions, shared principles, decision making structures and the broad components of sustainability appraisal. There is also a broadly held view that the management of unacceptable risks to human health, water, ecology and other receptors of concern remains the primary driving force and decision making rationale for remediation. Sustainable remediation seeks to find the optimal means of delivering the risk management objectives needed (which may include early stage interventions in project planning to avoid unnecessary remediation work, by for example changing the land use configuration of a planned development).

Where there are divergences in approach these are linked to the detailed implementation of sustainability assessment and ensuring linking decision making structures to the prevailing national jurisdictional context (policy, regulations, etc.).

Definitions provided in the framework documents share an opinion that sustainability encompasses environmental, societal and economic elements, and specific considerations of sustainability used in sustainable remediation decision making need to be drawn in a proportionate and balanced way from across all three elements. Definitions also tend to emphasise that the aim of sustainable remediation is to find the optimal available project option as a result of this assessment. 
Definitions are typically supported by principles more or less explicitly stated in the surrounding text of the framework document. The division of important themes across definitions and principles varies from framework to framework. However across definitions and principles the following broad themes are widely held:

- Human health/Environmental health/Risks - RBLM

- Benefit optimisation/Better remediation solutions

- Three pillars/elements of sustainability

- Sustainability assessment/Assessment implied

- Decision making process

- Transparency

- Stakeholders

- Emphasis on technical environmental issues and actions

- Long term vision

- (Contaminated land) Management

- Sound science

- Use of indicators/metrics

- Complying with regulations

- Judicious limited resources use/use of resources

- Record keeping

- Safe working practices

- Emphasis on socio-economic factors/community impacts.

Most of the decision-making structures presented in the framework documents identify a series of stages in planning and decision-making where sustainable remediation considerations could be made. These stages may be described differently but in broad terms two particular stages are widely identified: a stage of decision-making which leads to remediation objective setting, and a stage of decision-making where specific remediation approaches are appraised against these objectives. Several initiatives suggest that opportunities for improving overall project sustainability are greater if the benefits and downsides of the different remediation alternatives available can be considered as early as possible in project decisionmaking, and not just at the final stage of selecting best approach for pre-specified remediation objectives.

A related discussion is that while the sustainable brownfield regeneration domain is recognised as broader than the sustainable remediation one, the nexus between these two is clearly recognised as important in the majority of sustainable remediation frameworks. This could be explained by two reasons: first, because, due to this link, if specialists involved in sustainable remediation consider regeneration when defining remediation site-specific sustainability objectives, remediation will directly influence the regeneration process, thus sustainable remediation is the trigger to sustainable regeneration. Conversely, sustainability principles can be applied first to a broad regeneration project and then transferred to all steps, remediation included. In conclusion, sustainability principles should be incorporated the onset of project planning to drive sustainable remediation and regeneration concurrently and in harmony.

Clear and transparent objective setting and boundary definitions are widely recommended for sustainability assessments to ensure that the purpose and function of decision making is unambiguous and that different options are truly compared on a like-for-like basis.

There is divergence across the framework documents in how the scope of sustainability is agreed (i.e. the range of individual considerations taken to be encompassing the environmental, social and economic elements of sustainability). There appears to be a generally shared ambition that the different stakeholders involved in a project (e.g. site owner, service provider, regulator, planner, etc.) should all have an opportunity to contribute to the selection of these sustainability criteria. In addition, most frameworks 
describe tiered approaches to sustainability assessment, where initially simple methods are used, progressing on to more complex methods only where simpler assessments are unable to resolve a decision. However, several initiatives appear to favour prescriptive (top-down) quantitative assessment methods which reduces flexibility for incorporating a wide range of sustainability criteria and which subverts a tiered approach.

Case studies can play an important role in knowledge transfer since they demonstrate and track success of sustainable remediation implementation. Success is highlighted through reduction in natural resources consumed and environmental (e.g., carbon) footprints, cost-effectiveness of project implementation, and remedial outcomes meeting community needs and facilitating regeneration. Case studies published among the initiatives showcase that sustainable remediation is widely adopted among various stakeholder groups. In addition, sustainable remediation can be applied to any project and not dependent on size, complexity, and strong community presence. Templates provided by each initiative facilitate comparability when evaluating sustainable remediation practices implemented on projects.

This very paper is a demonstration of the international community of shared interest in sustainable remediation. Representatives of the various initiatives reviewed have all contributed to the drafting of this shared paper.

As a final consideration, we hope that this collection and comparison of different initiatives approaches and visions on sustainable remediation could be of support for practitioners approaching and starting developing their own documents on this topic. Also, terms of common use in sustainable remediation should now be more agreed and familiar, so that harmonisation and fruitful dialogue can be facilitated. Important work is being done by standards initiatives such as ASTM and ISO which are setting out broadly shared understanding of definitions and principles and good practice in establishing sustainable remediation frameworks and assessment tools. Of these the developing 'informative' standard from ISO (2015) offers a platform for new jurisdictions to rapidly adopt and benefit the shared learning of the initiatives described in this paper.

\section{Disclaimer}

The presentation of the case studies by the various initiatives does not constitute an endorsement of their content and of the Sustainable Remediation value by the initiatives themselves or complete application of a set framework, but an effort to collect examples of application of SR principles, with associated challenges and results. 


\section{Acknowledgements}

The authors gratefully acknowledge the receipt of the following financial support for the research, authorship, and/or publication of this article: This work was supported by the European Commission's Seventh Framework Programme in the theme ENV.2010.3.1.5-2-Environmental technologies for brownfield regeneration (Grant agreement no. 265364) - project TIMBRE - www.timbre-project.eu. Paul Bardos' contribution was supported by the University of Brighton, UK.

\section{References}

Albano, C., Falconi, M., 2014. Insight on themes for upcoming Sustainable Remediation Conference: Agenda and Host Country Goals. http://www.surfitaly.it/documenti/11Albano Falconi SR USEPA.pdf

ASTM E1984-03. Standard guide for process of sustainable brownfields redevelopment (withdrawn 2012). Astm Int., West Conshohocken, PA. www.astm.org.

ASTM E2876-13, 2013. Standard guide for integrating sustainable objectives into cleanup. Astm Int., West Conshohocken, PA, www.astm.org.

ASTM E2893-13, 2013. Standard guide for greener cleanups. Astm Int., West Conshohocken, PA, www.astm.org.

Bardos, R.P., Lewis, A. J., Nortcliff, S., Mariotti, C., Marot, F., Sullivan, T., 2002. Review of Decision Support Tools for Contaminated Land Management, and their use in Europe. Final Report. Austrian Federal Environment Agency, 2002 on behalf of CLARINET, Spittelauer Lände 5, A-1090 Wien, Austria. Available from:

http://www.umweltbundesamt.at/en/umweltschutz/altlasten/projekte1/international1/clarinet/clarinet r esults/

Bardos, P., Bakker, L., Darmendrail, D., Harries, N., Holland, K., MacKay, S., Pachon, C., Slenders, H., Smith, G., Smith, J., Wiltshire, L., 2013. Sustainable and green remediation - global update, ThS E3 Sustainable use of the subsurface. Proc. Aquaconsoil 2013 Barc. Spain April 2013.

Bardos P., 2014. Progress in Sustainable Remediation. Wiley Online Library (wileyonlinelibrary.com). DOI: 10.1002/rem.21412.

Bardos, R.P., Bone, B.D., Boyle, R., Evans, F., Harries, N., Howard, T. and Smith, J.W.N., 2016. The rationale for simple approaches for sustainability assessment and management in contaminated land practice. Accepted for Science of the Total Environment DOI 10.1016/j.scitotenv.2015.12.001

Bolton, M., Dridan, J., Innes, L., Northway, A., Shiels, S., Warwick, B. (EPA Victoria), Naidu, R., Kennedy, B., Srivastava, P. (CRC CARE), 2013. Precinct-scale urban renewal - challenges and opportunities. Remediation Australasia, Issue 14, pp. 18-21.

Brombal, D., Wang, H., Pizzol, L., Critto, A., Giubilato, E., Guo, G., 2015. Soil environmental management systems for contaminated sites in China and the EU Common challenges and perspectives for lesson drawing. Land Use Policy, 48, pp. 286-298.

Brundtland. G.H., 1987. Our Common Future. World Commission on Environment and Development. http://www.un-documents.net/wced-ocf.htm

CABERNET (Concerted Action on Brownfield and Economic Regeneration Network), 2006. Sustainable brownfield regeneration: CABERNET Network Report. www.cabernet.org.uk/resourcefs/427.pdf. 
CL:AIRE, 2010. A Framework for Assessing the Sustainability of Soil and Groundwater Remediation, SuRFUK, http://www.claire.co.uk/index. php?option=com phocadownload\&view=file\&id=61\&ltemid=230.

CL:AIRE, 2011. SuRF-UK Framework Annex 1: The SuRF-UK Indicator Set for Sustainable Remediation Assessment.

SURF-UK http://www.claire.co.uk/index.php?option=com phocadownload\&view=category\&download=262:annex1-the-surf-uk-indicator-set-for-sustainable-remediation-assessment\&id=8:initiatives\&start=40\&ltemid=230 (accessed 8.18.15).

CL:AIRE, 2013. SURF-UK case study. Shell Terminal. Facility. Madeira. SuRF-UK http://www.claire.co.uk/index.php?option=com phocadownload\&view=file\&id=365:case-studybulletins\&ltemid $=25$ (accessed 8.18.15)

CL:AIRE, SURF International, 2015. www.claire.co.uk/surfinternational http://www.claire.co.uk/index.php?option=com content\&view=article\&id=616:surfinternational\&catid $=963 \& /$ temid $=140$

CLARINET (Contaminated land rehabilitation Network for Environmental Technologies), 2002. Sustainable management of contaminated land: an overview. http://www.commonforum.eu/Documents/DOC/Clarinet/rblm_report.pdf.

Common Forum and NICOLE, 2013. Risk-informed and sustainable remediation joint position statement. http://www.nicole.org/uploadedfiles/2013\%20NICOLE-Common-Forum-Joint-Position-SustainableRemediation.pdf (accessed 8.18.15).

Cundy, A.B., Bardos, R.P., Church, A., Puschenreiter, M., Friesl-Hanl, W., Müller, I., Neu, S., Mench, M., Witters, N., Vangronsveld, J., 2013. Developing principles of sustainability and stakeholder engagement for gentle remediation approaches: the European context. J. Environ. Manage. 129, pp. 283-291.

Döberl, G., Wepner-Banko, M., Müller, D., 2012. The 2nd International Conference on Sustainable Remediation 2012 November 14 - 16, 2012 in Vienna, Austria Conference Summary by Umwelt Bundesamt. http://www.umweltbundesamt.at/fileadmin/site/aktuelles/veranstaltungen/2012/sustrem2012/Summary SustRem 2012 Conference EAA.pdf

Döberl, G., Ortmann, M., Frühwirth, W., 2013. Introducing a goal-oriented sustainability assessment method to support decision making in contaminated site management. Environmental Science \& Policy 25: 207-217.

Döberl, G. and Müller-Grabherr, D., 2015. Recent Trends in the Assessment of Sustainable Remediation Does the Tail Wag the Dog? AquaConSoil2015 Conference Proceedings. http://www.aquaconsoil.org/assets/aquaconsoil_proceedings_2015.pdf

GoT-HOMBRE (Glossary of Terms for Holistic Management of Brownfield Regeneration), 2014.

Hadley, P. W. and Harclerode, M., 2015. Green Remediation or Sustainable Remediation: Moving From Dialogue to Common Practice, Remediation Journal Spring 2015: 95-115 DOI: 10.1002/rem.21427.

Harclerode, M., Risdale, D. R., Darmendrail, D., Bardos, P., Alexandrescu, F., Nathanial, P., Pizzol, L., Rizzo, E., 2015. Integrating the Social Dimension in Remediation Decision-Making: State of the Practice and Way Forward. Remediation Journal, 26(1).

Holland, K., Karnis, S. and Kasner, D.A., Brandt Butler, P., Hadley, P.W., Nathanail, P., Ryan, J., Smith, L.M., Wice, R., 2013. Integrating Remediation and Reuse to Achieve Whole-System Sustainability Benefits, Remediation Journal, Spring 2013: 5-17 DOI: 10.1002/rem.21345. 
HOMBRE (Holistic Management of Brownfield Regeneration), 2014. http://www.zerobrownfields.eu/ (accessed 8.31.15).

Hunt, J.W. and Smith, G.J., 2015. Application of sustainable remediation principles in an Australasian context. Remediation Australasia. Issue 172015.

IISD (International Institute for Sustainable Development), 1996.

https://www.iisd.org/measure/principles/progress/bellagio_full.asp

International Standards Organisation - ISO (2015) ISO/DIS 18504 Soil quality -- Guidance on sustainable remediation http://www.iso.org/iso/home/store/catalogue tc/catalogue detail.htm?csnumber=62688 Accessed November 2015

ITRC (Interstate Technology and \& Regulatory Council), 2011a. Green and Sustainable Remediation: State of the Science and Practice. http://www.itrcweb.org/GuidanceDocuments/GSR-1.pdf (accessed 8.18.15).

ITRC, 2011b. Green and sustainable remediation: a practical framework http://www.itrcweb.org/GuidanceDocuments/GSR-2.pdf (accessed 8.18.15).

MPCA (Minnesota Pollution Control Agency), 2012. Green and Sustainable Remediation, Petroleum Remediation Program. c-prp1-10. http://www.pca.state.mn.us/index.php/view-document.html?gid=18427.

NICOLE (Network for Industrially Contaminated Land in Europe), 2010. Road map for sustainable remediation. $\quad$ http://www.nicole.org/uploadedfiles/2010-wg-sustainable-remediation-roadmap.pdf (accessed 8.18.15).

NICOLE, 2012. How to implement sustainable remediation in a contaminated land management project? NICOLE sustainable remediation work group 2012 report. http://www.nicole.org/uploadedfiles/wgsustainableremediation-finalreport.pdf (accessed 8.18.15).

Pintér, L., Hardi, P., Martinuzzi, A., Hall, J., 2012. Bellagio STAMP: principles for sustainability assessment and measurement. Ecol. Indic. 17, pp. 20-28.

RESCUE (Regeneration of European Sites in Cities and Urban Environments), 2003. Analytical sustainability framework in the context of brownfield regeneration in France, Germany, Poland and the UK. Final report of work package 1. www.rescue-europe.com (accessed 8.31.15).

RESCUE <http://www.rescue-europe.com/> (accessed 8.31.15)

Rizzo, E., Pesce, M., Pizzol, L., Alexandrescu, F., Giubilato, E., Critto, A., Marcomini, A., Bartke, S., 2015. Brownfield regeneration in Europe: identifying stakeholder perceptions, concerns, attitudes and information needs. Land Use Policy 48, pp. 437-453.

RPIC (Real Property Institute of Canada), 2015. http://www.rpic-ibic.ca/en/events/federal-contaminatedsites-fcs-national-workshop/2016-fcs-national-workshop/sustrem-home

SURF, 2009. Sustainable remediation white paper: Integrating sustainable principles, practices, and metrics into remediation projects. Remediat. J. 19 (3), pp. 5-114.

SuRF-ANZ, 2011. A framework for assessing the sustainability of soil and groundwater remediation. http://landandgroundwater.com/page/sustainable-remediation-forum-for-australia-new-zealand-surf-anz.

SURF-Italy, RECONNET, 2014. Libro bianco 2014. Sostenibilità applicata alle bonifiche in Italia. http://www.surfitaly.it/documenti/SURF\%20Italy\%20Libro\%20Bianco_2014_FINAL.pdf (accessed 8.18.15). 
SuRF-NL, 2015. Cahier Duurzaam Saneren (Guidance on Sustainable Remediation). http://www.surfnl.com/publicaties/CAHIER DuurzaamSaneren Beheren.pdf

Swartjes, F. A., ed. Dealing with contaminated sites. From theory towards practical application. Springer Science \& Business Media, 2011.

Tang, Y-T. and Nathanail, C.P., 2012. Sticks and Stones: The Impact of the Definitions of Brownfield in Policies on Socio-Economic Sustainability. Sustainability 2012, 4(5), 840-862; doi: 10.3390/su4050840

TIMBRE (Tailored Improvement of Brownfield Regeneration in Europe), 2014. http://www.timbreproject.eu/ (accessed 8.20.15).

United Nations, 2015. Transforming our world: the 2030 Agenda for Sustainable Development. Security Council Resolution A/RES/70/1.

USACE (US Army Corps of Engineers), 2012. USACE Decision Framework for Incorporation of Green and Sustainable Practices into Environmental Remediation Projects. http://employee.uxb.com/Publications/USACE/IGD\%2010-01.pdf (accessed 8.2014).

US EPA (United States Environmental Protection Agency), 2002. Brownfields and land revitalization: Definition of brownfields. Retrieved fromhttp://www.epa.gov/brownfields/overview/glossary.htm.

US EPA, CLU-IN, 2004. Cleaning up the Nation's waste sites: markets and technology trends. https://cluin.org/download/market/2004market.pdf.

US EPA, 2008. Green remediation: Incorporating sustainable environmental practices into remediation of contaminated sites EPA/542/R/08/002, USA.

US EPA, 2011. Brownfields definition. http://www.epa.gov/brownfields/overview/glossary.htm.

US EPA, 2012. Methodology for Understanding and Reducing a Project's Environmental Footprint. EPA 542-R-12-002, USA.

http://clu-in.org/greenremediation/methodology/docs/GC Footprint Methodology Feb2012.pdf

US EPA, 2015. Superfund Community Involvement Handbook.

http://www2.epa.gov/superfund/community-involvement-tools-and-resources\#tab-2

US EPA National Contingency Plan (NCP), (40CFR300.430(e)(9)(iii)) Nine criteria for evaluation, http://www.ecfr.gov/cgi-

bin/retrieveECFR?gp=\&SID=f1fd100ddf2a0af99f28befc97b33cff\&mc=true \&n=sp40.28.300.e\& $r=S U B P A R T \& t$ $\mathrm{y}=\mathrm{HTML}$ Hse40.28.300 1430.

US Navy, 2012. Department of the Navy Guidance On Green And Sustainable Remediation. Retrieved from:

http://www.navfac.navy.mil/content/dam/navfac/Specialty\%20Centers/Engineering\%20and\%20Expedition ary\%20Warfare\%20Center/Environmental/Restoration/er_pdfs/gpr/navfacesc-ev-ug-2093-env-gsr-

20120405r1.pdf

Van Liedekerke, M., Prokop, G., Rabl-Berger, S., Kibblewhite, M., Louwagie, G., 2014. Progress in the management of Contaminated Sites in Europe. JointResearchCentre Reference Report. http://eusoils.jrc.ec.europa.eu/ESDB_Archive/eusoils_docs/other/EUR26376EN.pdf

Vegter, J.; Kasamas, H., Lowe, J., 2001. CLARINET: Sustainable management of contaminated land, an overview. Final Report of CLARINET. 
WDNR (Wisconsin Department of Natural Resources), 2012. Green \& Sustainable Remediation Manual, A Practical Guide to Green and Sustainable Remediation in the State of Wisconsin. Pu b - R R - 911 . http://dnr.wi.gov/files/pdf/pubs/rr/rr911.pdf

Williams, K., Dair, C., 2005. A conceptual model of sustainable development. Working paper 3. Oxford Institute for Sustainable Development, Cities Unit, Oxford. 